\title{
PRIVILEGED, PROBLEMATIC OR PROBLEM-SOLVING PARTNERSHIP: THE IMAGE OF THE EUROPEAN UNION IN CONTEMPORARY TURKEY
}

\begin{abstract}
This paper aims to analyze the role of EU-Turkey relations in Turkish public debate since 2002, when the Justice and Development Party took power. The Republic of Turkey filed an application to accede to the European Economic Community (the predecessor of the European Union) in 1987; however, the accession negotiations proceeded extremely slowly until the entire process came to an impasse in 2018. Although currently Turkey and the European Union share many common problems (e.g. migration crisis, threat of terrorism, energy security), their cooperation is very limited and thus often ineffective. The author argues that recent developments in Turkey have been shaped by President Erdoğan's anti-Western rhetoric and are dominated by domestic factors (i.e. inward oriented). In order to present Turkey's attitudes towards the EU, the source analysis focused on identifying basic assumptions and objectives of Turkish foreign policy The analysis revealed that here are three possible scenarios for future partnership between Turkey and the EU: optimistic, pessimistic, and realistic.
\end{abstract}

\section{Key words}

Republic of Turkey, Turkish foreign policy, Justice and Development Party, European Union-Turkey relations, European Neighbourhood Policy 


\section{Introduction}

Almost the entire 20th-century international image of the Republic of Turkey was shaped by its relations with Western Europe and the US. Founded in 1923, after the fall of the Ottoman Empire, the Turkish state relinquished its imperial past in favor of thorough modernization and secularization of all spheres of public life, with the aim of becoming a highly developed liberal democracy. The principle of prioritizing relations with the West was formulated by the founder of modern Turkey, Mustafa Kemal Atatürk, whose views set the political framework of the Republic (Zürcher, 2004, p. 189). As an originator of a radical transformation of the state, Atatürk claimed that abandoning the practices introduced during the Ottoman rule would lead to the socially expected improvement of the general standard of living in Turkey. Therefore, Turkish political elite decided to tighten strategic ties with the state's Western allies and to gradually distance themselves from the neighboring regions. Recognized by almost all consecutive governments as the official doctrine of Turkish domestic and foreign policies, the Kemalist ideology became the foundation for a series of structural reforms which were to be conducted in accordance with European standards (Ciftci, 2013, pp. 148-151). In order to consolidate the Kemalist model in social consciousness, a powerful army acted as a guardian of the republican political values. In line with the procedure developed after Atatürk's death in 1938, the Turkish Armed Forces had an unwritten right to intervene in cases of civilian politicians violating these norms (Uluçakar, 2018, pp. 87-89).

Nevertheless, in the previous century, there were two anti-European narratives in Turkey; however, they remained outside the political mainstream. One of them was the nationalist model that referred to the idea of Pan-Turkism, based on the ethnic unity of the Turkic peoples (Turks, Azeris, Kazakhs, Kyrgyz, Uzbeks, Tatars). According to proponents of Turkish nationalism, cooperation of the central authorities with the United States and Western Europe threatened the security of the Turkic populations, a significant part of which was at that time citizens of the Union of Soviet Socialist Republics. By proclaiming cultural distinctiveness based on the concept of "Turkicness", ideologists associated with Turkish nationalist thought called for non-engagement in global disputes arising from the Cold War conditions. Consequently, an alternative solution for the Turkic peoples was supposed to be an attempt to create their own exclusive platform for regional cooperation (Bilgin, 2018, pp. 335-342). 
The second type of non-mainstream narrative was a conservative model, referring to values related to religion. Representatives of this vision emphasized the crucial place of Turkey in the world of Islam. Interestingly enough, some of them even appealed for focusing international activity of the Turkish state solely on the Middle East (Yeşiltaş, 2014, pp. 27-33). Public support for the conservative model, which increased considerably over time, resulted from dissatisfaction of a large part of the society with the rapid pace of changes introduced by the Kemalist governments. Among various social groups, the rural population in particular did not accept the authorities' efforts to exclude Islam from public life. In the national debate their views were represented by intellectuals cultivating the Ottoman tradition, in which secular and religious aspects of power were combined and complemented each other (Kılıç, 2007, pp. 126-130). Nevertheless, both conservative and nationalist narratives remained on the margins of Turkish politics for decades.

Despite the presence of those competing models, for the vast majority of the 20th century Turkish citizens supported the Kemalist vision, recognizing European integration as the key development opportunity for Turkey. After the end of World War II, the central authorities continued the process of strengthening relations with Western Europe and the US. Accordingly, the Republic of Turkey was one of the first states to join the Council of Europe (1949) and the North Atlantic Treaty Organization (1952). The next step would have been accession to the European Economic Community (EEC), but due to reasons that are discussed later in this paper, the official application was not submitted by the Turkish government until 1987 (Arikan, 2006, pp. 241-243). Numerous difficulties that emerged during the negotiations did not discourage the authorities in Ankara from attempting to fulfill the goal, namely Turkey's membership in European structures. Completion of the accession process was also one of the main foreign policy objectives of the Justice and Development Party (Adalet ve Kalkınma Partisi, the AKP), which won the parliamentary elections in November 2002. Now, after nearly twenty years of uninterrupted rule of the AKP, the prospect of Turkey's accession to the European Union is very distant. This article attempts to answer the question which factors influenced the change of Turkish policy towards the EU.

\section{Research design and methodology}

The main objective of this paper is to analyze the policy of Recep Tayyip Erdoğan and the government of the Justice and Development Party towards 
the European Union and its institutions, with particular attention paid to the period since 2014, when Turkish political system underwent a fundamental change. That year, Recep Tayyip Erdoğan, a long-time Prime Minister and the leader of the ruling AKP, was elected President of Turkey in the first ever direct popular vote. Subsequently, the new president began the process of concentration and centralization of power in the state, incrementally changing the political system from parliamentary to presidential model (Turan, 2018, pp. 79-82). Those actions coincided with the intensification of critical attitudes and confrontational narratives towards the EU that were publicly expressed by representatives of the Turkish political elite.

A drastic shift in the AKP's approach towards the idea of European integration is problematic from the EU perspective as Turkey, for years considered as a reliable partner, has now become an opponent (or even a rival) to several European initiatives. Differences of views and interests are apparent on issues such as the Syrian civil war, priorities of NATO, relations with the Russian Federation, or policies towards the Western Balkans (Özcan, 2017). It should be noted at this point that the first signs indicating modification of Turkish foreign policy appeared in the first decade of the 21st century. According to the "strategic depth" doctrine, proposed by Ahmet Davutoğlu and subsequently implemented by the Erdoğan government, Turkey has gradually abandoned one-dimensional and EU-centered policy and expanded its political influence to neighboring regions (North Africa, Middle East, Central Asia). The Justice and Development Party's ultimate goal in this context was to achieve the status of a regional power that would manage to transform the international order (Erşen, 2014, pp. 187-189). Although this conception had failed during the Arab Spring, President Erdoğan and the AKP did not decide to restore positive relations with the European Union. On the contrary, Turkish rhetoric towards the EU has been constantly sharpening in recent years (Efegil, 2016, pp. 56-57).

This article is divided into four main sections. The first part introduces theoretical assumptions adopted to analyze source and empirical materials. It is followed by the description of the historical process which led to Turkey being declared a candidate for the EU membership. The third part analyzes the current role of the European Union in the AKP's policy and presents the change in the approach of Turkish authorities towards the idea of European integration. The final section shows three alternative scenarios for the future of Turkey-EU relations. Accordingly, the research hypothesis of this article states that Turkish political debate on the EU has been shaped by President Erdoğan's anti-Western rhetoric and is dominated by domestic factors. 
As literature on EU-Turkey relations has been dominated by Western European perspective, this research is based primarily on Turkish sources. Thus an in-depth analysis of views and stances of President Erdoğan and the AKP government will contribute to a comprehensive summary of Turkey's contemporary policy towards European integration. The research has employed a wide range of written sources concerning EU-Turkey relations, including academic publications, official documents and reports, policy briefs, press releases, etc. Consequently, the basic research methods here are source analysis and triangulation of data sources. In the case of presidential and governmental documentation as well as public speeches and interviews of Turkish foreign policy-makers, the article uses analysis of the decision-making process. By examining recent events from the standpoint of the political center, the paper presents the discourse on the EU as framed by Turkish authorities. The purpose of this method has been also to determine the importance of mutual relations in the regional strategy of the AKP. In turn, foreign policy analysis confronts theoretical considerations with Turkish diplomatic activities in the international arena. As a result, a set of most significant variables influencing Turkish foreign policy has been identified and then studied. Additional research methods include historical method, process tracking method, and comparative analysis. Subsequently, in the prognostic part the article exploits a collected catalogue of features (through extrapolation method) in order to create scenarios for future developments.

\section{Theoretical framework}

The theoretical basis for the research is role theory in international relations as it provides a wide range of tools useful in examining diplomatic activities of states. Thanks to this, it is possible to identify a number of factors shaping a foreign policy. This theoretical perspective covers all tasks and duties performed by a state in bilateral relations as well as its international roles (Yigit, 2015, pp. 11-14).

Following broader research on social roles, role theory in international relations was developed in the second half of the 20th century. This theoretical approach was developed by Kalevi Holsti, a Canadian political scientist of Finnish origin. In 1970 Holsti published the findings of his research in which he had studied links between the structure of the international system and foreign policies of selected states. Thus Holsti significantly facilitated scientific exploration of political practice by referring its individual determinants to specific elements forming theoretical conceptions (Holsti, 1970, pp. 241-247). Other researchers who contributed to the development of role theory in international relations are 
Lisbeth Aggestam, Carl Backman, Michael Barnett, James Rosenau, Stephen Walker, and Ziemowit Jacek Pietraś (Zając, 2010, pp. 24-25).

Drawing from achievements of other academic disciplines (e.g. anthropology, psychology and sociology), role theory in international relations underlines the importance of identity in interstate relations. Hence in this respect it refers to the assumptions of constructivism. Moreover, as a result of its broad research perspective and methodological openness, role theory may be considered a vital source of information while analyzing a state's behavior in the international arena and explaining complex processes that occur on regional or global scale. However, there is no universally accepted definition of role in social sciences. Therefore, each of the leading international relations theories (realism, structuralism, liberalism, postmodernism) refers to this subject in different way. This research adopts the definition developed by Justyna Zając, who describes international roles of a state as a "system of actions and influences in the international arena, determined primarily by the state's identity and its international position" (Zając, 2015, pp. 134-135).

According to the fundamental premises of role theory, a state performs its international roles through foreign policy. Specific roles can be identified after analyzing declarations and actions of political leaders in the international sphere. In his research, Holsti described seventeen major types of international roles: bastion of revolution (liberator), collaborator, defender of faith, example, mediator-integrator, developer, independent, bridge, regional protectee, isolate, etc. The typology proposed by Holsti has been systematically developed and refined by other researchers, e.g. Margareta and Charles Hermann, Stephen Walker, and Lisbeth Aggestam (Thies, 2012).

Naturally, a state can play several roles simultaneously, which depends on the perception of its own identity and attitude towards other participants of the international system. However, in such situations there is a risk of conflict between state roles, which may lead to serious turbulences in its foreign policy. Solving such problems arising from this process is complicated and requires great conceptual and organizational skills from state authorities (Zając, 2010, pp. 35-38). Predominantly, the conflicts mentioned above result from certain discrepancies between three primal types of international roles that concern different aspects of diplomatic practice (conceptions, prescriptions, and performances). According to Holsti's typology, role conceptions include all announcements and declarations of political leaders regarding future activities of a state in the international arena. In turn, role prescriptions (also known as role expectations) are related to internal and external conditions in which a given 
participant of the international system is situated. Finally, role performances imply specific actions taken by state authorities at regional and global levels (Holsti, 1970, pp. 236-240). In conclusion, a state involved in a series of complex international roles must regularly control whether the entirety of activities that constitute the sphere of its foreign policy comply with the principle of coherence (Harnisch, 2011, pp. 8-9).

In reference to the literature on the subject, it is noteworthy that political scientists and researchers have studied the changing dynamics of Turkish political discourse towards the EU by applying various theoretical perspectives (e.g. neorealism, securitization theory, critical theories, and different approaches within the constructivist paradigm). However, recent advances in role theory offer an essential alternative in exploring phases of contemporary relations between Turkey and the European Union. As explained by David McCourt, the state's self-image in the international arena has been shaped by constant interaction of internal and external factors, which directly affects the evolution of its political identity and fundamental interests. Accordingly, international conduct of a state may thereby gain new orientation (McCourt, 2014, pp. 37-40). In this approach, the key driver conditioning the modification process is greater self-awareness of entities constituting the state (e.g. political, intellectual and financial elites). Therefore, a state with a certain level of consciousness pursues its goals in relations with other participants of the international system and assumes roles that are considered optimal for its interest. In line with the presented theoretical perspective, and by implementing the aforementioned three types of roles, a state becomes embedded in society, which further increases its self-confidence. Since the roles function also as transmitters of social moods, citizens themselves have an influence on forming the identity of a state. Due to the unpredictability of internal and external interactions, the state's identity in the field of international relations is exposed to permanent changes depending on specific circumstances (Harnisch, 2016, pp. 4-13). In view of the foregoing, a part of this research bases its analysis on the shift of Turkish policy towards the European Union on role theory in international relations.

\section{Historical background}

Westernization and integration with Europe have been priorities of successive governments since the very foundation of the modern Turkish state. Relations between the Republic of Turkey and the European Union have a relatively long history that dates back to the late 1950s. On 31 July 1959, the then Prime Minister 
Adnan Menderes applied to the European Economic Community (EEC) for associate membership. The application was accepted on 11 September of the same year (Kihtir, 2004, p. 124). Efforts to strengthen cooperation were reflected in signing the Agreement Creating an Association between the Republic of Turkey and the European Economic Community (commonly known as the Ankara Agreement) on 12 September 1963. The aim of the treaty, which came into force in 1964, was to create optimal conditions for Turkey's full membership in the EEC. Hence, the most important stage in this process involved ensuring deepened economic integration of Turkey with the EEC member states. Provisions of the Ankara Agreement were the foundation of an institutional structure with such bodies as the Association Council, the Association Committee, the Turkey-EU Joint Parliamentary Commission (JPC), the Joint Advisory Committee, the Customs Cooperation Committee (CCC), and the Customs Union Joint Committee. In 1970 the Additional Protocol to the Agreement was signed. The document concerned gradual elimination of custom tariffs and quantitative restrictions between Turkey and the EEC (Tepeli \& Aydın, 2015, pp. 34-37).

However, due to serious economic problems that Turkey faced at the turn of the 1970s, the Ankara Agreement was not completed. The three-stage adaptation process was supposed to result in Turkey being subject to regulations related to common customs tariff, but Turkish economy was not prepared for such profound changes at that time (Aksoy et al., 2017, pp. 65-66). Thus, contacts between Turkey and the EEC were significantly reduced in the mid-1970s. This was also caused by an unstable political situation in Turkey (e.g. three military coups between 1960 and 1980) (Akinc1, 2013, pp. 40-41).

Relations between Turkey and the European Economic Community were resumed in 1983 when the Turkish Armed Forces allowed restoration of civilian government. With the normalization of domestic policy, the Republic of Turkey returned to its intention to establish positive economic ties with the EEC. In order to demonstrate Turkish commitment to the idea of European integration, the government of Turgut Özal submitted an application for full membership on 14 April 1987 (Uğur \& Aksoy, 2015, pp. 169-170). Prime Minister Özal was aware that real and permanent stabilization of Turkish political system would be possible only after joining the EEC. Otherwise, the actual power in the state would be exercised for decades by the army that could either rule from behind the scenes, or form a strong military government. Although the official document was submitted ahead of the date specified in the accession calendar of the Ankara Agreement, the response of the EEC Commission was not released immediately. It was announced on 18 December 1989 that the Turkish 
application had been rejected due to the necessity to conclude the integration process within the Community itself, which was supposed to be accomplished in 1992. Moreover, the Commission raised number of concerns related to the level of economic, political, and social development in several areas of the state. Therefore, it was proposed to continue the accession process under provisions of the Ankara Agreement without setting a specific date for the full membership (Çalış \& Çakır, 2018, pp. 439-440).

Despite the obvious disappointment with the Commission's opinion, the EEC proposal was eventually approved by the Turkish government. In subsequent years, Turkey focused on effective implementation of provisions of the Additional Protocol, which were to create a customs union. This goal was achieved on 5 March 1995, when the Association Council announced that on 1 January 1996 a customs union would be established between Turkey and the European Union (the EEC was incorporated by the newly formed EU in 1993). Thus, one of the most important stages in the entire integration process was completed, and the Turkish-European relations entered a new dimension, which was confirmed next year by the Commission's decision to accelerate cooperation with Turkey in every field (Ağır \& Metin, 2016, pp. 12-13).

However, during the European Council meeting in Luxembourg in December 1997, the Republic of Turkey was not listed as an official EU candidate. According to the European Council, Turkey's fundamental problems included persisting insufficiencies in its national integration and coordination mechanism, particularly in the area of political system and economy. Importantly, the EU has clearly defined the conditions that Turkey had to meet in order to become a full member of the Community. Nevertheless, this time Turkish government did not accept explanations of the European Council. During the political debate that ensued after the EU's announcement, it was even considered to terminate the dialogue with the European Union without reaching an agreement. From Turkey's perspective, allegations regarding the state of respect for human rights in the country were particularly unwarranted. Reacting to the Turkish stance, the European Commission released a document "A European Strategy for Turkey", which contained guidelines for future integration. Subsequently, Turkey's efforts to adapt its policy to the Copenhagen criteria were positively assessed in the Progress Report published in 1998 by the European Commission (Demirkiran et al., 2010, pp. 60-61).

A milestone in the history of the EU-Turkey relations was the Helsinki European Council held on 10-11 December 1999, where the representatives of EU member states officially approved Turkey's candidacy. Thus the Republic 
of Turkey formally joined countries that had candidate status in Luxembourg. Turkey was also included in the EU financial support program that aimed to support reforms in the pre-accession period (Loğoğlu, 2001, pp. 178-180). A detailed scheme for further integration was to be formulated in the "Accession Partnership Document for Turkey", a plan developed jointly by Brussels and Ankara. The document was declared on 8 March 2001, and soon afterwards the Turkish government approved a national program for adoption of the EU acquis. In the following months, multidimensional cooperation between Turkey and the European Union intensified noticeably. At this stage, the main goal was to officially open accession negotiations. With the purpose of adjusting Turkey's political system to standards set out in the Copenhagen criteria, the Turkish authorities introduced a number of structural reforms, including amendments to the constitution (Üstün, 2017, pp. 88-89).

\section{EU-Turkey relations during the AKP rule}

The Justice and Development Party was founded in 2001 by politicians associated with the Islamist-conservative movement, and headed by a former mayor of Istanbul Recep Tayyip Erdoğan. Taking advantage of serious disorganization on the Turkish political scene, triggered by the consequences of the so-called postmodern coup d'état, the AKP won a decisive victory in the 2002 parliamentary elections. In its political program, the Justice and Development Party announced intensification of efforts aimed at integrating Turkey with the European Union, as well as emphasized the necessity to improve relations with its Middle Eastern neighbors (Çarkoğlu, 2002, pp. 152-154). The latter postulate stood in clear contradiction to the principles of Kemalist ideology, which provoked a quick reaction of the Turkish Armed Forces. The General Staff, which at the beginning of the 21st century still had strong influence on Turkish political system, obliged the AKP government to immediately accelerate the EU accession process. Under military pressure, Turkish diplomacy initially concentrated on strengthening cooperation with Western allies (Aknur, 2015, p. 136). However, politicians of the Justice and Development Party attempted to act in a multifaceted manner, seeking to establish positive contacts with other regions. Among them the most important was the Middle East, a key area in the "strategic depth" doctrine. The figure who became responsible for determining directions of Turkish foreign policy in that period was Professor Ahmet Davutoğlu, nominated in 2003 as chief adviser to Prime Minister Erdoğan's cabinet (Arin, 2017, pp. 47-49). 
Turkey's willingness to continue the integration process, even after profound exchange of political class following the 2002 elections, was received positively by the EU. From the AKP's perspective, proceeding in accordance with the guidelines set by Brussels could be beneficial in terms of consolidation of power, as one of the EU principal requirements implied an imposition of civilian control over the military (Mufti, 2014, pp. 34-35). Consequently, during the initial years of the Justice and Development Party's rule, Turkey increased efforts to finally commence the accession negotiations. For the purpose of underlining a proEuropean attitude of the new government, Prime Minister Erdoğan paid official visits to several EU countries (Akdoğan, 2010, p. 12).

As the vast majority of democratic reforms initiated by previous governments were continued by the AKP, the Turkish Armed Forces and the Kemalist elites, which portrayed Erdoğan and his associates as Islamic fundamentalists, were deprived of credibility. As a result, the aforementioned opposition forces did not possess the necessary instruments to effectively challenge legitimacy of the ruling party's actions. In particular, limitation of the army's role in the Turkish political system during the first years of the AKP rule led to significant consequences in Turkey's recent history (Cansever \& Kiriş, 2015, pp. 373-374). Another important change resulting from the enhanced cooperation between the Turkish government and EU institutions was gradual improvement in the level of respect for human rights, with special regard to the situation of the Kurdish minority, previously treated as second-class citizens. These events, along with active foreign policy that was constantly involved in solving regional conflicts, allowed the Justice and Development Party to create the image of Turkey as a credible state in the international arena, an ideal bridge connecting the East and the West (Aslan, 2018, pp. 45-46). Much less noticeable at that period was the fact that all actions described above served also to consolidate the power in the state and to weaken the AKP's opponents at home and abroad.

Turkey's degree and extent of compliance with the Copenhagen criteria was positively assessed by the EU in the "2004 Regular Progress Report for Turkey", which was subsequently confirmed at the European Council Summit in Brussels on 17 December 2004. Moreover, it was agreed that accession negotiations between the EU and Turkey would be initiated on 3 October 2005 (Özer, 2010, pp. 99-101). Despite emerging doubts regarding Turkey's problematic relations with Greece and Cyprus, the negotiation process began within the planned timeframe. The entire catalogue of rules, procedures, and individual chapters approved by both parties was included in the document "Negotiation Framework". The official commencement of the accession process was considered in Turkey as 
a huge success of the AKP government, but soon afterwards the first major discrepancies between Turkey and the EU arose during actual negotiations. Hence, enthusiasm of the Turkish society for potential membership in the European Union diminished (Güreşci, 2010, pp. 76-79).

In this context, it is worth mentioning the results of a study in which preferences of voters on Turkey's accession to the EU were examined. The survey was conducted by a research group led by Dr. Mustafa Ozan Şahin before the 2007 parliamentary elections and indicated growing indifference towards the European Union among Turkish citizens. Out of 2,000 respondents, 30 percent supported efforts to bring negotiations to a positive conclusion, while 29 percent opted against Turkey's membership in the EU. For the remaining 41 percent of the interviewees the issue of European integration was rather irrelevant. In terms of political preferences, the biggest supporters of the EU (69\%) were voters of the Kurdish Democratic Society Party (Demokratik Toplum Partisi, DTP). Next in the survey (32\%) were the AKP supporters. None of the other parties exceeded 30 percent. The vast majority of participants in the survey perceived the European Union as a Christian institution focused primarily on economic integration. Therefore, religiously and culturally distinct Turkey, with its cheap labor and large social inequalities, could threaten the interests of the Community. According to the respondents, slow pace of accession negotiations did not result from the insufficient AKP reforms but was caused by unexpressed reluctance of the EU member states towards Turkey. Interestingly, every fifth respondent suggested creating an alternative regional organization that would include either Muslim or Turkic community (Şahin, 2011, pp. 114-127). This is an obvious reference to the two anti-European narratives described in the introductory part.

The weakening of pro-European sentiments in the Turkish society coincided with a decline in dynamics of the accession negotiations. In 2007 the AKP won a double victory as the party not only received over 46 percent of votes in the parliamentary elections but also its candidate Abdullah Gül was elected the new president. The presidential election was particularly important since the Justice and Development Party managed to overcome the resistance of the military, which had threatened to use force in the event that Gül would become the head of state (Akınc1, 2013, pp. 52-53). The office of the President was the last highranking civilian institution that had not yet been controlled by the AKP. After the election of Abdullah Gül, another step was reached in the process of consolidating power in Turkey. With broad public support and consistent expansion within the state structures, the AKP began to limit influences of groups 
associated with the Kemalist elites. Under the guise of democratization, the government was successively (i.a. through constitutional amendments) increasing its control over the army, the judiciary, the media, and universities. Initially, the European Commission recognized these activities as measures necessary for efficient reconstruction of the state system (Y1lmaz, 2014, pp. 66-68). However, it soon became evident that the AKP was focused primarily on imposing its own political will, repeatedly violating EU standards set out in the "Negotiation Framework".

The most apparent example of departing from European instructions was general lack of respect for defendants' rights during trials against people suspected of attempting to overthrow the AKP government (the "Ergenekon" and "Balyoz" cases). According to numerous reports of EU institutions and non-governmental organizations, the level of observance of human rights and civil liberties in Turkey also decreased at the end of the 2000s (Güner, 2013, pp. 47-49). In addition, there was no expected breakthrough in the Kurdish issue (AB Başkanlığ1, 2011). It follows from the foregoing that the EU negotiation process was exploited by the AKP as a tool to maximize the power and weaken the opposition. When Prime Minister Erdoğan decided that cooperation with the European Union was no longer necessary in implementation of his policies, Turkey's interest in accession negotiations was reduced significantly, which resulted in the emergence of serious problems between both sides.

The bilateral relations worsened most dramatically in the area of foreign policy. In 2009 Ahmet Davutoğlu was appointed the Minister of Foreign Affairs and gained even greater influence on Turkish diplomacy. In accordance with the "strategic depth" doctrine, Minister Davutoğlu was primarily focused on Turkey's ties with Muslim countries, reducing his commitment in issues related to the EU accession (Telatar, 2015, pp. 493-499). Moreover, Turkish regional involvement (particularly in the Middle East and North Africa) was contrary to the EU position, as expansive policy of the authorities in Ankara threatened the contemporary order in that part of the world. The intentions of the AKP were revealed after the outbreak of the Arab Spring, when Turkey engaged in internal conflicts in several Arab countries, attempting to shape the course of local socio-political processes in line with its own interests (Tüysüzoğlu, 2013, pp. 299-302). Turkish actions during that period led to multiple diplomatic disputes between Turkey and the European Union. In addition, the majority of the EU member states openly criticized Turkish support for radical opposition forces in Syria, Libya, and Egypt. Subsequently, the failure of Turkish foreign policy in the Middle East and North Africa was explained in a public debate 
by Prime Minister Erdoğan as a hostile act of the EU, which allegedly feared Turkey's growing position in the region. This confrontational rhetoric caused further cooling in mutual relations (Efegil, 2016, pp. 51-53).

The radical reduction in the level of security and stabilization in Turkish neighborhood affected also the domestic policy adopted by the Justice and Development Party. In the following months, the government was attempting to monopolize power in the state more than ever before, removing the last bastions of the Kemalist opposition. At that time, Turkish authorities became intolerant towards criticism from EU institutions that called for a return to the implementation of pro-democratic reforms (Sunar, 2013, pp. 433-436). From the AKP's perspective, these appeals were considered as an unauthorized interference in Turkey's internal affairs, which resulted in a steady increase in tensions between Ankara and Brussels. Within a few years, the image of the European Union in the rhetoric of the ruling party changed from a friendly and reliable partner into one of the main threats to Turkish interests in the international arena (Yllmaz, 2019, pp. 26-28).

Significant part of the Turkish society opposed this drastic shift in the AKP's attitude, as manifested by a series of protests that began in spring 2013 in Istanbul and spread rapidly into other metropolitan areas. The protesters demanded correction of the rulers' policy as well as continuation of the democratization process. In response to these calls, the authorities used force against demonstrators. The action taken by the government was condemned by the EU, which expressed further concerns about the state of democracy in Turkey. However, the AKP ignored this stance and adopted the tactic of social polarization, setting liberal and pro-Western residents of major cities against conservative and religious rural communities. As a result, the protests soon ceased due to the decreasing public support for demands of the demonstrators (Akçay, 2017, pp. 47-48).

Along with progressing unilateralism of the government's activities, tensions and divisions began to emerge among the ruling class itself. The uncompromising policy of the AKP was criticized by Fetullah Gülen, the leader of conservative "Hizmet" movement. Previously, Gülen and his followers had been Erdoğan's allies in the process of removing the Kemalist elites from public positions, but after achieving this goal, their visions of Turkey's future turned out to be significantly different. At the turn of 2014, the Gülenists revealed several corruption scandals aimed at striking the AKP leadership (Parlak, 2015, pp. 534-536). However, Erdoğan again successfully defended the party against allegations of undermining democracy in Turkey, which resulted in his victory in the first-ever general presidential election in August 2014. After being elected President, Recep Tayyip 
Erdoğan did not observe the constitutional principle of impartiality, still acting as an actual party leader and a head of the executive branch. Consequently, the EU issued another series of opinions and recommendations criticizing Turkey for violating democratic standards. This turned out to be another opportunity for Erdoğan to wield his anti-Western rhetoric when he accused several EU member states of supporting terrorist groups in the region (Özcan, 2017).

Approximately since that time the critical narrative towards the European Union (and in general the whole West) has become a permanent element of the policy of President Erdoğan and the Justice and Development Party. In recent years, Turkish authorities have explained almost every serious problem of the state as being caused by hostile EU actions. This was the case of the loss of parliamentary majority after the elections in June 2015, the failed coup d'état in July 2016, or the great economic crisis that began in Turkey at the turn of 2018 (Çoban Oran, 2018, pp. 436-439). In addition, the Turkish ruling class has been presenting the EU and the West as rivals in Turkey's regional initiatives, of which the Syrian civil war is the best example. Over the years, the AKP has built its image of the only party defending traditional Turkish values, which has contributed to guaranteeing the party stable support of voters. Since the majority of citizens accept all government decisions, it is possible to apply or even manipulate social moods in order to implement specific actions in domestic and foreign policies. From the European perspective, accusations of destabilizing Turkey by the EU may be absurd, yet this strategy perfectly suits the current internal situation in the state and facilitates the process of mobilizing the AKP's electorate against external threats. On the other hand, the EU itself had had an indirect impact on the radical change in Turkey's approach to European integration. After all, the accession process had been hampered for years by several EU member states that had openly questioned the idea of Turkish membership in the Community and pointed to cultural, religious, and economic differences existing between the sides (Çalış \& Metkin, 2017, pp. 25-30). The current public debate in Turkey uses this fact as an argument for definitive withdrawal from cooperation with the EU. The Turkish approach has been also affected by recent developments in Europe, where far-right, populist, and anti-Muslim organizations have emerged and gained support. Thus, the number of Turks who perceive the vision of the EU membership as a real opportunity for Turkey is constantly decreasing (Bayrakl1, 2019, pp. 363-366).

Therefore, even the only relative success in EU-Turkey relations in recent years, i.e. the "Refugee Agreement" signed in March 2016, has made no positive impact on the AKP rhetoric. According to the document, the authorities 
in Ankara agreed to accept refugees with irregular status from the EU member states. In return, the European Council promised Turkey financial support, visafree policy, and acceleration of the accession process. Four years after signing the agreement both sides repeatedly accuse each other of violating its provisions. In the opinion of Turkey, European legal systems are dysfunctional and thus the entire deportation process is significantly prolonged (Kizllkan, 2018, pp. 102-111). On the other hand, observers from Brussels point out that Turkey has been misusing EU funds allocated to provide decent living conditions for migrants and asylum seekers in refugee camps. Moreover, the Turkish government continues to demand the abolition of visas and simplification of accession negotiations (Kaplan, 2018, pp. 5-8). The EU cannot approve this claim since Turkey ceased to comply with the Copenhagen criteria long ago. Due to the lack of breakthrough in mutual relations, President Erdoğan has recently announced that Turkey is strong enough to act effectively in the international arena without the consent and support of the EU. Consequently, regular contacts between Turkey and the European Union are limited practically only to the implementations of particular economic interests (Bozkaya \& Kincal, 2018, pp. 113-121).

\section{Conclusions and perspectives}

The analysis of Turkish foreign policy towards the European Union, conducted as part of this research, indicates that the significant change in approach of the AKP and President Erdoğan to the idea of European integration has been influenced primarily by internal factors. Having observed the developments on the Turkish political scene in recent years, it can be said that politicians of the Justice and Development Party possess the ability to properly read and then to immediately respond to shifts in public mood. Over decades of its rule in Turkey, the AKP has refined the reaction mechanism to such an extent that the party is able to manipulate social processes in order to achieve its particular political goals. Accordingly, the Justice and Development Party has managed to consolidate power, overcome the opposition, introduce the presidential system, and finally change the EU's image in public awareness (Kirişci \& Toygür, 2019). In President Erdoğan's rhetoric, the basic objective of these consistently taken steps was to strengthen the international position of Turkey and, consequently, to achieve the status of a regional power. This intention guided the AKP from the very beginning of its rule and has been successively implemented over the years (Erdağ, 2013, pp. 63-71). At some point, regional interests of Turkey and the EU had to collide and since then, the Turkish government has expressed its anti-Western 
attitude more explicitly. Although the vision of powerful Turkey presented in Ahmet Davutoğlu's "strategic depth" doctrine has never been implemented and the entire conception failed during the Arab Spring, President Erdoğan and his ministers have not abandoned their confrontational narrative towards Europe and the US. Since Turkish foreign policy is fully subjected to national policies, the authorities in Ankara must create the image of Turkey as a strong and independent state in the international arena (Lami, 2018, pp. 51-52). Thus it is perpetuated among the citizens that the AKP is the sole party that can provide Turkey with expected development and prosperity in all sectors of the state. In this context, the anti-European rhetoric of President Erdoğan and the Justice and Development Party is addressed predominantly to the electorate in Turkey and - to a much lesser extent - to its international partners. Moreover, recent failures of the AKP regional initiatives have resulted in significant limitation of Turkey's diplomatic activity (Balc1 et al., 2019, pp. 73-76). In addition, the Turkish authorities are aware that total separation from the European Union would have disastrous consequences especially for the economy, which is heavily dependent on trade with the EU member states. Therefore, Turkey's international discourse on the European Union is noticeably less confrontational and radical compared to its domestic narrative (Duman, 2018, pp. 87-90).

Referring to the original typology of international roles proposed by Holsti, it can be argued that during the AKP rule there has been a significant modification of Turkish foreign policy towards the EU on all three levels (i.e. role conceptions, role prescriptions, role performances). In the initial period (2002-2005), the Turkish government attempted to control the principle of coherence between the roles, cooperating with the European Union to complete the integration process. However, despite the opening of accession negotiations, Turkey began to expand its regional influence in line with the adopted "strategic depth" doctrine. In retrospect, it turned out that assumptions of Ahmet Davutoğlu's political vision were based on too idealistic premises, as a result of which effective implementation of the entire strategy has become complicated in practice. By adopting the role of regional leader, the AKP sought to challenge the geopolitical order in Turkish neighborhood. Nevertheless, improper execution of additional roles (e.g. defender of faith, faithful ally, example) led to a serious conflict at the level of role performances, which in turn resulted in the defeat of Turkish diplomacy during the Arab Spring (2010-2013). In the case of relations with the EU, the change of role from collaborator to independent was dictated by the urge to consolidate power in the state, increasingly anti-European social moods, and different strategic interests. However, diplomatic failures in other 
regions indicate that the AKP's confrontational rhetoric towards the EU may not have brought political benefits that were intended before the fundamental shift in Turkish foreign policy.

Based on the previous findings, it is possible to create three alternative scenarios for future development of the Turkish-EU relationship. The first, optimistic scenario assumes slow return to positive relations between both parties. In that sense, it would refer to the so-called "Privileged Partnership", a political project proposed already in 2004 by Germany, which implied deeper cooperation (i.e. in defense, security, and foreign policies) without Turkey's actual membership in the EU (Akçay, 2016, pp. 15-16). Having realized that in current geopolitical circumstances the vision of joining the European Union is very distant, the Turkish government may decide to resume more effective relations with the EU member states, especially in the event of a prolonged economic crisis in Turkey. It should be noted that during previous turbulences, Turkish economy recovered relatively quickly thanks to closer cooperation with Europe. Therefore, it cannot be excluded that in the foreseeable future President Erdoğan will choose to moderate his rhetoric towards the EU and promote further strengthening of trade ties between Turkey and Europe. A hypothetical reset in mutual relations may lead to resumption of accession negotiations, which, in longer perspective, might even result in Turkey's full membership in the EU. However, due to the recent developments, this scenario is the least probable outcome.

In turn, the second scenario is a pessimistic one. It projects a systematic deterioration in mutual relations, which would eliminate any possibility of cooperation between Turkey and the EU. As a consequence of increasing polarization in the international arena, two opposing political blocs would emerge, with Turkey and the EU as fierce rivals. Thus any prospects for rebuilding positive contacts would be lost. Relations between Turkey and the EU would be limited to absolute minimum resulting from the objective geographical proximity. Constant accusations and provocations would become the only form of dialogue, while collisions of interests would occasionally cause visible tensions in the entire region. Trade ties would be maintained as low as possible to guarantee relative profits for both parties. All other forms of contact would be suspended indefinitely. In pursuing its foreign policy goals, Turkey would seek for alternative partners (e.g. Russia, China, Iran), so that the issue of Turkey's accession to the EU would be permanently terminated (Şahin \& Özel, 2018, pp. 59-66). This scenario is unfortunately more likely to happen than the first one, especially if the EU becomes more assertive in responding to Turkish aggressive rhetoric and confrontational actions in the region. 
However, the most probable of these three scenarios is the one predicting that the level of EU-Turkish relations would remain at the current stage for a long time. Due to the problems described above, it is difficult to predict a prompt return to productive relations between Turkey and the EU. This state of affairs results from erroneous actions and decisions of Ankara and Brussels, which has been acknowledged by both parties. Nevertheless, despite the significant differences in opinions and interests, the scale of challenges and threats in contemporary international politics is so vast that neither Turkey nor the EU can afford to completely break their diplomatic contacts. Therefore, it is anticipated that both sides would adopt in mutual relations the strategy of solving common problems, which has already been quite effectively tested during the migration crisis (Aydın, 2018, pp. 36-38). This scenario does not assume that contacts between Ankara and Brussels would be as positive as over a decade ago, but at this stage it is sufficient for both partners to create a problem-solving mechanism, without the necessity to renew accession negotiations. Moreover, there are several challenges where cooperation between Turkey and the EU would be beneficial for the entire world (e.g. stabilization of the Middle East and North Africa, fight against terrorism, sustainable energy policy). The first step towards positive dialogue on these issues would be the rejection of confrontational rhetoric to ensure mutual trust between Ankara and Brussels. Ultimately, shared respect for fundamental values is the foundation for achieving common goals, even in the area of foreign policy.

\section{REFERENCES}

AB Başkanlığı. (2011). Türkiye 2011 Yılı İlerleme Raporu. Retrieved from https://www. ab.gov.tr/files/AB_Iliskileri/AdaylikSureci/IlerlemeRaporlari/2011_ilerleme_raporu_tr.pdf

Ağır, H., \& Metin, M. (2016). Türkiye-Avrupa Birliği Dı̧̧ Ticaret Göstergeleri Üzerine Bir Değerlendirme. Kahramanmaraş Sütçü İmam Üniversitesi İktisadi ve İdari Bilimler Fakültesi Dergisi, 1(6), 11-26.

Akçay, E. (2017). Pozitif Gündem Ve Sonrasindaki Gelişmeler Işiğında Türkiye-AB İlişkileri. International Journal of Economics and Administrative Studies, 19, 43-58. Akçay, E. (2016). Türkiye-AB İlişkileri Ve “İmtiyazli Ortaklik” Meselesi. Toros Üniversitesi İISBF Sosyal Bilimler Dergisi, 3(5), 11-30.

Akdoğan, Y. (2010). Tarihe Düşülen Notlar: 17 Aralık AB Zirvesinin Perde Arkası. İstanbul: Alfa Yayıncılık. 
Akınc1, A. (2013). Türk Siyasal Hayatında 1980 Sonrası Darbeler ve E-Muhtıra. Trakya Üniversitesi Sosyal Bilimler Dergisi, 2(15), 39-58.

Aknur, M. (2013). Civil-Military Relations During the AK Party Era: Major Developments and Challenges. Insight Turkey, 4(15), 131-150.

Aksoy, G. P., Tuğ, B., \& Kaymak, A. (2017). Türkiye’nin Avrupa Birliğine Giriş Sürecinin Türk Basınındaki Sunumu. İNİF E-Dergisi, 1(2), 63-83.

Arikan, H. (2006). Turkey and the EU: An Awkward Candidate for EU Membership? Aldershot: Routledge.

Arin, K. Y. (2017). Turkey's New Foreign Policy: the Quest for Regional Hegemony in the Middle East? The Copernicus Journal of Political Studies, 2, 45-57.

Aslan, D. (2018). Turkey: a Bridge between East and West and its Catalyst Role in Alliance of Civilizations Initiative. Kwartalnik Naukowy Uczelni Vistula, 1(55), 41-48. Aydın, E. (2018). Avrupa Birliği Mevzuatında Güvenli Üçüncü Ülke Kavramı ve Türkiye-AB Geri Kabul Anlaşmasına Yansımaları. Milletlerarası Hukuk ve Milletlerarası Özel Hukuk Bülteni, 1(38), 11-40.

Balc1, A., Cicioğlu, F., \& Küçükboz, D. (2019). Türkiye’nin Ekseni Kayiyor Mu? Bir Literatür Değerlendirmesi. Akademik Araştırmalar ve Çalışmalar Dergisi, 10(20), 66-81.

Bayraklı, E., \& Özdemir, Ç. (2019). Understanding the Ever-Changing Dynamics in Turkish-EU Relations during the AK Party Era (2002-2018). Mukaddime, 1(10), 355-374.

Bilgin, O. (2018). Türk Milliyetçiliği ve Kemalizm Meselesi Hegemonya, Asimilasyon, Mücadele. Akademik Hassasiyetler, 5(10), 331-360.

Bozkaya, Ö., \& Kincal, A. (2018). Türkiye-Avrupa Birliği İlişkileri ve Suriyeli Yerinden Edilmiş Kişiler Bağlamında Türkiye'nin Göç Politikasındaki Gelişimin Değerlendirilmesi. Göç Araştırmaları Dergisi, 2(4), 90-126.

Cansever, N., \& Kiriş, H. M. (2015). Türkiye'de Ordu - Siyaset İlişkileri Çerçevesinde Ak Parti - TSK Etkileşimine Bakış. Süleyman Demirel Üniversitesi İktisadi ve İdari Bilimler Fakültesi Dergis, 3(20), 361-384.

Ciftci, K. (2013). The Kemalist Hegemony in Turkey and AKP as an 'Other'. L'Europe en Formation, 1(367), 143-169.

Çalış, Ş. H., \& Çakır, F. (2018). Türkiye-AB İlişkilerinde Yunan-Rum Faktörü. Süleyman Demirel Üniversitesi Sosyal Bilimler Enstitüsü Dergisi, 1(32), 432-449.

Çalış, Ş. H., \& Metkin, K. (2017). Algı Ve Yanılgı: AB Normları, Türkiye’nin Üyeliği ve AK Parti'nin Rolü. Marmara Avrupa Çalışmaları Dergisi, 2(25), 1-39.

Çarkoğlu, A. (2002). The Rise of the New Generation Pro-Islamists in Turkey: The Justice and Development Party Phenomenon in the November 2002 Elections in Turkey. South European Society and Politics, 2(7), 123-156.

Çoban Oran, F. (2018). Türkiye-AB İlişkilerinde Yeniden Canlanmadan "Hedef Değişismine” Doğru. Yönetim Bilimleri Dergisi, 16(31), 427-442. 
Demirkiran, Ö., Çiçek, E., Eltetik, H., \& Sarikçioğlu, M. (2010). Türkiye-Avrupa Birliği İlişkilerinde "Son Dönem". Niğde Üniversitesi İktisadi ve İdari Bilimler Fakültesi Dergisi, 1(3), 57-75.

Duman, M. (2018). 15 Temmuz Askeri Darbe Girişiminin Türkiye-Avrupa Birliği İlişkilerine Etkisi. Liberal Düşünce Dergisi, 23(90), 71-95.

Efegil, E. (2016). AK Parti Hükümetinin Orta Doğu Politikası ve ABD Yönetimi ile Batılı Uzmanların Eleştirileri. Akademik Bakış, 9(18), 45-58.

Erdağ, R. (2013). Türkiye'nin Stratejik Kültürü ve Dış Politikada Yansıması. Akademik Incelemeler Dergisi, 1(8), 51-76.

Erşen, E. (2014). Rise of New Centres of Power in Eurasia: Implications for Turkish Foreign Policy. Journal of Eurasian Studies, 2(5), 184-191.

Güner, S. Ş. (2013). Alternative Futures for the European Union-Turkey Accession Negotiations. Central European Journal of International and Security Studies, 2(7), 40-59.

Güreşci, E. (2010). Türkiye - Avrupa Birliği (AB) İlişkileri Sürecinde Kamuoyunun Tutumu Ve Değerlendirilmesi. Doğuş Üniversitesi Dergisi, 1(7), 72-85.

Harnisch, S. (2011). Role Theory: Operationalization of Key Concepts. In S. Harnisch, C. Frank, H. W. Maull (Eds.), Role Theory in International Relations: Approaches and Analyses (pp. 7-15). New York: Routledge.

Harnisch, S. (2016). Role Theory and the Study of Chinese Foreign Policy. In S. Harnisch, S. Bersick, J. C. Gottwald (Eds.), China's International Roles: Challenging Or Supporting International Order? (pp. 3-21). New York: Routledge.

Holsti, K. J. (1970). National Role Conceptions in the Study of Foreign Policy. International Studies Quarterly, 3(14), 233-309.

Kaplan, Y. (2018). Analysing Instability as a Future for an Institutionalization Process: the EU, Turkey and the Issue of Migration. European Journal of Futures Research, 6(16), 1-10.

Kihtir, A. (2004). 2000'li Yıllarda Avrupa Birliği - Türkiye İlişkilerine Genel bir Bakış. İstanbul Üniversitesi İletişim Fakültesi Dergisi, 20, 123-131.

Kirişci, K., \& Toygür, İ. (2019). Turkey's new presidential system and a changing West: Implications for Turkish foreign policy and Turkey-West relations. Brookings: Turkey Project Policy Paper, 15. Retrieved from https://www.brookings.edu/wp-content/ uploads/2019/01/20190111_turkey_presidential_system.pdf

Kılıç, M. (2007). Erken Cumhuriyet Dönemi Türk Milliyetçiliğinin Tipolojisi. Süleyman Demirel Üniversitesi Fen Edebiyat Fakültesi Sosyal Bilimler Dergisi, 16, 113-140.

Kızılkan, Z. B. (2018). Avrupa Birliği ve Türkiye’nin Suriyeli Mültecilerin Dayanıklılığını Geliştirme Stratejiler. Mukaddime, 1(9), 95-114.

Lami, B. (2018). Recalibration of Turkish Foreign Policy During AKP Era. Central European Journal of International and Security Studies, 3(12), 35-56.

McCourt, D. M. (2014). Britain and World Power since 1945: Constructing A Nation's Role in International Politics. Ann Arbor: The University of Michigan Press. 
Mufti, M. (2014). The AK Party's Islamic Realist Political Vision: Theory and Practice. Politics and Governance, 2(2), 28-42.

Özcan, M. (2017). AB-Türkiye İlişkileri ve Suriye Krizi. İnsani ve Sosyal Araştırmalar Merkezi, 40. Retrieved from https://insamer.com/rsm/files/AB-TR-ILISKILERI-VESURIYE-KRIZI(1).pdf

Özer, A. (2010). Avrupa Birliğine Tam Üyeliğin Eşiğinde Türkiye. Yönetim ve Ekonomi Araştırmaları Dergisi, 1(16), 89-105.

Parlak, İ. (2015). Yerel Seçimler Ulusal Düşmanlar. Ankara Üniversitesi SBF Dergisi, 3(70), 507-540.

Sunar, B. (2013). Adalet ve Kalkınma Partisi’nin Dış Politika Söyleminde Temalar: Türkiye Bülteni Üzerine Bir İnceleme. Süleyman Demirel Üniversitesi İktisadi ve İdari Bilimler Fakültesi Dergisi, 3(18), 431-454.

Şahin, G., \& Özel, Y. (2018). Çatışmadan İşbirliğine: Türkiye, Rusya ve İran. Elektronik Siyaset Bilimi Araştırmaları Dergisi, 16(9), 53-70.

Şahin, M. O. (2011). Türk Seçmeninin İdeolojik ve Siyasi Durumu Bağlamında Avrupa Birliği Algısı. Güneydoğu Avrupa Araştırmaları Dergisi, 20, 101-130.

Telatar, G. (2015). Ak Parti’nin Düzen Kurucu Dış Politika Söylemi Ve Ortadoğu. Alternatif Politika, 3(7), 490-523.

Tepeli, E., \& Aydın, A. H. (2015). Avrupa Birliği Ve Türkiye-Avrupa Birliği İlişkilerinin Gelişme Trendi. Kahramanmaraş Sütçü İmam Üniversitesi İktisadi ve İdari Bilimler Fakültesi Dergisi, 1(5), 29-44.

Thies, C. G. (2011). International Socialization Processes vs. Israeli National Role Conceptions: Can Role Theory Integrate IR Theory and Foreign Policy Analysis? Foreign Policy Analysis, 1(8), 25-46.

Turan, M. (2018). Türkiye'nin Yeni Yönetim Düzeni: Cumhurbaşkanlığı Hükümet Sistemi. Social Sciences Research Journal, 3(7), 42-91.

Tüysüzoğlu, G. (2013). Milenyum Sonrası Türk Dış Politikası: Yeni Osmanlıcılık ve Türk Avrasyacılığı Ekseninde İnşa Edilen Bir Pragmatizm. Alternatif Politika, 3(5), 295-323.

Uğur, Ö., \& Aksoy, M. (2015). Avrupalılaşma Kavramı ve Türkiye’nin Demokratikleşme Sürecine Etkisi. Karadeniz Teknik Üniversitesi Sosyal Bilimler Enstitüsü Sosyal Bilimler Dergisi, 5(10), 163-180.

Uluçakar, M. (2018). Türkiye’de Sivil-Asker İlişkilerinin Temel Açmazları ve Uzlaşı İmkânları. Toros Üniversitesi Sosyal Bilimler Dergisi, 5(8), 78-103.

Üstün, Ç. (2017). Can EU Act as a Democracy Promoter? Analysing the Democratization Demand and Supply in Turkey-EU Relations. Romanian Journal of European Affairs, 1(17), 85-99.

Yeşiltaş, M. (2014). Stratejik Derinlik’in Jeopolitik Tahayyülü. Türkiye Ortadoğu Çalışmaları Dergisi, 1(1), 25-56.

Yilmaz, G. (2019). From EU-phoria to EU-phobia? Changing Turkish Narratives in EUTurkey Relations. Baltic Journal of European Studies, 1(9), 20-32. 
Yılmaz, G. (2014). Türkiye, Avrupalılaşma Ve Yerel Değişim. Marmara Avrupa Çalışmaları Dergisi, 2(22), 64-84.

Yigit, N. (2015) Arab Spring in Berlin and Paris: German and French Foreign Policy Between Continuity and Change. Hamburg: Anchor Academic Publishing.

Zając, J. (2010). Role Unii Europejskiej w Regionie Afryki Północnej i Bliskiego Wschodu. Warszawa: Wydawnictwa Uniwersytetu Warszawskiego.

Zając, J. (2015). Teoria Ról Międzynarodowych. In R. Zięba, S. Bieleń, J. Zając (Eds.), Teorie i Podejścia Badawcze w Nauce o Stosunkach Międzynarodowych (pp. 127-151). Warszawa: Wydział Dziennikarstwa i Nauk Politycznych.

Zürcher, E. (2004). Turkey: A Modern History. London: I. B. Tauris. 